\title{
THE EXAMINATION OF EDUCATIONAL SYSTEM AT THE INDUSTRY 4.0 AMONG LECTURERS
}

Szerzők:

Moses Amanor Padi

Eszterhazy Karoly Egyetem

Andrea Benedek

Eszterhazy Karoly Egyetem

Első szerző e-mail címe: mpadi35@gmail.com

\section{Lektorok:}

\author{
Noémi Fiser \\ Eszterhazy Karoly Egyetem
}

Tamás Erdélyi (PhD)

Eszterhazy Karoly Egyetem

...és további két anonim lektor

\section{Absztrakt \\ AZ OKTATÁSI RENDSZER VIZSGÁLATA \\ AZ IPAR 4.0-BAN, OKTATÓK KÖRÉBEN}

Napjainkban a negyedik ipari forradalom többé már nem fikció, hanem valóság. Az Ipar 4.0 számos kihívást jelent a jelen kor munkavállalóinak, szakembereinek egyaránt. S habár az elmúlt években számos intézkedés, kormányzati tevékenység, projekt valamint $\mathrm{K}+\mathrm{F}$ erőforrás segítségével próbálták támogatni az átmenetet és motiválni a vállalati innovációs tevékenységet, ennek ellenére világosan látszik, hogy a képzett munkaerő még mindig hiányzik a rendszerből, melynek egyik oka, hogy az oktatás jelentős lemaradásban van a negyedik ipari forradalom kihívásaihoz képest. A kutatás elsődleges célja, hogy az Ipar 4.0 szempontból vizsgálja az oktatási rendszert. A kvalitatív kutatás az Eszterházy Károly Egyetem oktatói körében 2018-ban zajlott, ahol 26 oktatót véleményét kérdezték meg személyes mélyinterjú során. A megkérdezett oktatók véleménye szerint a kommunikáció, ma sokkal gyorsabb és hatékonyabb, mint korábban, s egyetértettek abban, hogy a technológia fejlesztése és a digitalizáció új kihívást, modern és gyakorlatias tudást, újabb képességek, készségek fejlesztését kívánja meg. Ám a jelenlegi eszközpark hiányosságokkal küzd és az oktatási rendszer sem feltétlenül a negyedik ipari forradalom elvárásainak megfelelően képes felkészíteni a hallgatókat. Több lehetőség elsősorban a mérnöki, informatikai képzés területén van.

Kulcsszavak: Ipar 4.0; Oktatás 4.0; emberi erőforrás, innováció

Tudományterület: közgazdaságtan, társadalomtudományok, pedagógia 


\section{Abstract}

The Industry 4.0 is no longer fiction, it is reality nowadays. Although in recent years several measures, government activities, projects and increased R\&D resources have motivated and assisted companies in their innovation activities. This resource will be not enough to the transition because the main resources, the qualified employees, are lacking from the system. The education shows a strong fallback compared to Industry 4.0. The primary research examines the education system from Industry 4.0 point of viewA primary research was carried out among lecturers at the campuses of the Eszterhazy Karoly University in Hungary in 2018, which focused on the education system from the point of view of Industry 4.0. The research applied the face - to - face one -on -one in-depth interview method. According to the opinion of the interviewed lecturers, communication is much faster and more effective today than before, and they agreed that the development of technology and digitalisation requires new challenges, modern and pragmatic knowledge, the development of new skills and abilities. However, the current technologies in the education has some deficiencies and the education system is not necessarily capable of preparing students with the expectations of the fourth industrial revolution. More opportunities are mainly in the field of engineering and IT.

Keywords: Industry 4.0; Education 4.0; Qualification, Human Resource, Innovation

Disciplines: econimoics, social sciences, pedagogy

Moses Amanor Padi és Andrea Benedek (2020): The examination of Educational System at the Industry 4.0 among lecrurers. Mesterséges intelligencia - interdiszciplináris folyóirat, II. évf. 2020/1. szám. 59-68. doi: 10.35406/MI.2020.1.59

The Industry 4.0 is no longer fiction, it is reality nowadays. Although in recent years several measures, government activities, projects and increased $R \& D$ resources have motivated and assisted companies in their innovation activities. This resource will be not enough to the transition because the main resources, the qualified employees, are lacking from the system. The education shows a strong fallback compared to Industry 4.0. There is a notion that this revolution will impact societal activities and mode of living and economic trends is therefore something that not just a few 'players' should be concerned about but must be a major concern for the entire society especially the providers of knowledge which are the educational institutions.

One can say that education and learning which prepares individuals to be equipped in their dispensation of both economic and civic duty to society and inventers of new 
ideas for societal development over many generations seem to lag behind the new era. Today, the educational system as has been affected over the years by trends of society that has somewhat a questionable form. Also, its level of complexity is not at par with the speed and scope of new trends of high technological advancement of society today.

The standardization and the modus operandi of the educational institutions over the years do not seem to be complex enough in giving students the requisite skill, competence and ability to be competitive on the economic spheres of society.

\section{Brief history}

\section{of the industrial revolution}

\section{and the definition of industry 4.0}

The term "Industrial Revolution" was coined by Auguste Blanqui, a French economist, in 1837 to denote the economic and social changes arising out of the transition from industries carried in the homes with simple instruments, to industries in factories with power-driven machinery in Britain, but it came into vogue when Arnold Toynbee, the great historian, used it in 1882.

The First Industrial Revolution used water and steam power to mechanize production. The Second used electric power to create mass production. The Third used electronics and information technology to automate production. Now a Fourth Industrial Revolution is building on the Third, the digital revolution that has been occurring since the middle of the last century. It is characterized by a fusion of technologies that is blurring the lines between the physical, digital, and biological spheres. There are three reasons why today's transformations represent not merely a prolongation of the third Industrial Revolution but rather the arrival of a Fourth and distinct one: velocity, scope, and systems impact (Schwab, 2016).

Industry 4.0 is the vision of increasing digitization of production. The concept describes how the so-called Internet of things, data and services will change in future production, logistics and work processes. In this context according to Buhr (2017) industry representatives also like to talk about a fourth industrial revolution. They are alluding to a new organization and steering of the entire value chain, which is increasingly becoming aligned with individual customer demands. The value chain thus has to cover the entire lifecycle of a product, from the initial idea through the task of developing and manufacturing it to successive customer delivery as well as the product's recycling, all the while integrating the associated services.

In another explanation MacDougall (2014) smart industry or industry 4.0 refers to the technological evolution from embedded systems to cyber - physical stems. He opined that put simply industry 4.0 represents the coming of a fourth industrial revolution on the way to internet of things, Data and services. MacDougall (2014) explained that decentralized intelligence helps create intelligent objects networking and independent process management with interaction of real and virtual worlds representing a crucial new aspect of 
manufacturing and production process. This simply means industrial production machinery no longer simply 'processes' the product but that the product communicates the machinery to tell it exactly what to do.

\section{Characteristics of Industry 4.0 and} significance for the employment market Industry 4.0 is driven by Digitization and integration of vertical and horizontal value chains, Digitization of product and service offerings and Digital business models and customer access. Industry 4.0 digitizes and integrates processes vertically across the entire organization, from product development and purchasing, through manufacturing, logistics and service. All data about operations processes, process efficiency and quality management, as well as operations planning are available real-time, supported by augmented reality and optimized in an integrated network. Horizontal integration stretches beyond the internal operations from suppliers to customers and all key value chain partners. It includes technologies from track and trace devices to real-time integrated planning with execution (PwC, 2017).

During the transition to Industry 4.0, the change in production structure will surely have consequences. With regard to the working and professional world, according to the assumptions, work will become more challenging and have more informal qualification requirements such as the ability to act independently, self-organization, abstract thinking-skills (Forschungsunion, acatech, 2013). In line with qualitative preliminary studies BIBB and IAB (2015) conducted with companies which have already intensively involved with the implementation of Industry 4.0, results show there will particularly be less need for simple, repetitive tasks and special knowledge applied. Key results of the study show that although the transition to Industry 4.0 can on one hand in fact yield an improvement in the economic development, on the other hand, however, based on the assumptions made in ten years there will be 60,000 fewer jobs than in the baseline scenario. At the same time, 490,000 jobs will be lost, particularly in the manufacturing sector, and approximately 430,000 new ones will be created. To a great extent, jobs "switch" between sectors, occupations and qualifications (Wolte et al., 016).

\section{Impact of industry 4.0 on higher education}

The core mission of higher education remains the same whatever the era. The goal of higher education is to ensure quality of learning via teaching, to enable the students to get the latest knowledge through exploratory research, and to sustain the development of societies by means of service (Xing and Marwala, 2017). They added that to sustain the competitive position among world higher education system, we need to radically improve educational services. In particular, we need to drive much greater innovation and competition into education.

But Wallner and Wagner (2016), questioned; how can we fulfill this obligation, 
when new professions pop up at an everfaster rate and relatively stable professional profiles are increasingly replaced by generalized skill sets? They answered by giving out the suggestion that 'the complexity we find in the 'outside' world is reflected in each and every aspect of our academic work. When it comes to cope with complexity, standardization is always tempting. But standardization always means simplification, and thus standardized programs cannot deliver what we need'. Today, all graduates face a world transformed by technology, in which the Internet, cloud computing, and social media create different opportunities and challenges for formal education systems. Xing (2017), they further ascertained that as students consider life after graduation, universities are facing questions about their own destiny especially employment.

\section{Method}

The study achieves its goal with the method of qualitative research, of which results presents the opinions of lecturers of the higher educational institutions.

Interviews were carried out (Heves County) with lecturers and teachers at the Eszterhazy Karoly University. The survey includes both male and female lecturers of higher learning institution. This target population was chosen because they constituted the respondents in the organization which was used as a case study giving the researcher the privilege to understand the perception and feeling with regards to their view of the current higher education system in the wake of the fourth industrial revolution.

Face-to-face, one-on-one interview was carried out and recorded with 26 lecturers from different departments of the university campuses.

During the research the random sampling was used for the interviews. Interviews were carried out in the Autumn of 2018.

The data processing of the depth interviews and information processing were carried out in an oral way, however, the research to unveil the relationships examines frequency, causal relationships, processes and consequences and sets up structures (Babbie, 2001).

\section{Results and findings}

Conceptual definition and Knowledge awareness of industry 4.0 among lecturers. With the exception of a few interviewed, majority of lecturers affirm their knowledge of the fourth industry revolution with some giving out examples of the driving forces of the term as (Figure1):

- Information processing with precision (Big data \& Analytics),

- VR equipment (Augmented Reality),

- Emails and data storage (Cloud Computing),

- 3D printing machines (Additive manufacturing).

There was no precise mention of technical term to the concept IR 4.0 by the educators, but related definitions were given by the educators to explain the concept, to which the researcher links these definitions to the technical term on the chart below. 
Figure 1: Knowledge Awareness of Industry 4.0 Core Technologies (Source: according to the www. industry40marketresearch.com, 2018, Amanor-Benedek, qualitative research interviews, 2018/ N=26)

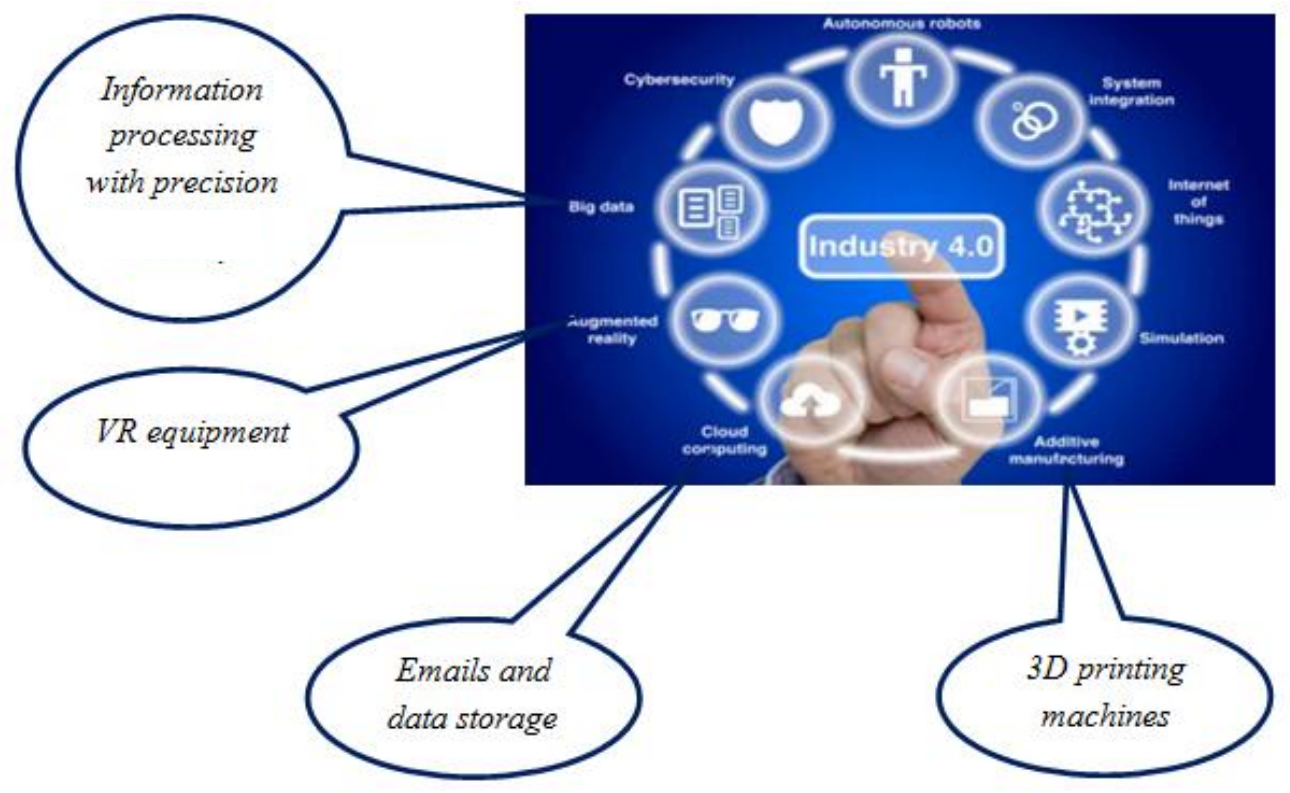

It emerged that educators are aware of how businesses and organizations are able to gather and analyze information regarding their business to almost a 95\% precision which help them to make major decision to better serve client and to remain competitive. This is what they reason that the concept IR 4.0 is or can be termed as a new world order which provides information with precision.

The findings of the survey also showed that educators appreciate the fact that education should be more practical than just the offering of theory, hence the development and use of virtual reality (VR) gadgets in schools can fast help solve the long-standing mere delivery of theory to life changing education of practical experience and knowledge acquisition. 'Today our kids in elementary school can learn and have practical experience with the help of the VR equipment. It can be introduced also in higher education for our students to better appreciate what we are teaching them -R.I EKE'.

Communication according to the lecturers, educators interviewed have become much easier and much effective with the use of emails today than some 15-20 years ago. They reasoned that it hasn't just been easy communicating but the cost of communicating today has become much cheaper than few decades ago. It was found out that storing of academic documents too has become more easy and safer. 
Over the past centuries and the immediate past decades, the system of education for preparing students for the future has been rather one that teaches subjects which are of practical basis in abstract. Educators from the survey agreed that the advancement in technology and digitization and development of equipment such as the $3 \mathrm{D}$ printers if introduced and used in the education system can help resolve the myth of delivering courses with practical basis in abstract. Some, however, affirm that the introduction of these equipment which could be very essential for their curriculum delivery is also far from reach as little is invested into education today by its stakeholders.

The respondents (lecturers) perception of the current higher education system is one that lacks;

- Modernity

- Collaboration

- Support

- Innovation and Change

From the Table 1 the respondents saw the current higher education system as not meeting the standards and current societal trend. It is still operating in the old-fashioned way just the way it was established centuries ago. They reasoned that the lack of collaboration on the part of education stakeholders and other economic share-holders has rendered the operations of the education system obsolete. One respondent asserted that ' $\mathrm{Ca}$ pital investment into education some twenty (20) years ago is much higher than what is been given today by key stakeholders to run the schools'
The research also found out that due to the lack of financial support from stakeholders' schools are unable to bring innovation and new curriculum to update old and obsolete subject. 'The making of these things requires money' - E. T.

\section{Conclusion}

The research results indicate that majority of lecturers from the University at various department are aware of the new industry revolution/evolution with their concerns that it may disrupt the educational system in a very profound way.

Results from the research also shows that lecturers/ teachers admit the current higher education system do not entirely prepare student for the future especially in the wake of high-tech society.

Modes of teaching and content delivery was pointed out by lecturers as a critical issue affecting the system in training of students. They believe that students must be taught based on their individual interest which will better enhance their skill for future prospects, the research shows.

The research gathered that students pursuing courses in the social sciences are more prone to the negative impact of the fourth industry revolution than those in the applied sciences. A collaborative effort must be pursued by higher educational institutions to develop relevant courses for students in the social sciences. 
Table 1: Perception of the current higher educational system by Lecturers (Source: Amanor-Benedek, own construction, qualitative research interviews, 2018/ N=26)

\begin{tabular}{ll}
\multicolumn{1}{c}{ FINDINGS } & \multicolumn{1}{c}{ COMMENTS BY LECTURERS } \\
\hline $\begin{array}{l}\text { Still traditional in its content delivery and mode of } \\
\text { teaching and learning. }\end{array}$ & $\begin{array}{l}\text { 'I think it must focus on the individual skill devel- } \\
\text { opment rather than delivery of theory' } \\
\text { 'We need to revise our teaching delivery methods } \\
\text { in the new age' }\end{array}$ \\
\hline $\begin{array}{l}\text { It lags behind the current new economic and } \\
\text { technological trends. }\end{array}$ & $\begin{array}{l}\text { 'There have been some changes, but these changes } \\
\text { have been very slow, our students may not be able } \\
\text { to compete on the job market in the near future. }\end{array}$ \\
& $\begin{array}{l}\text { It seems that we have kept the status quo for a } \\
\text { long time. I think it's time to improve our meth- } \\
\text { ods for different individuals in our schools" }\end{array}$ \\
\hline $\begin{array}{l}\text { Efforts of the higher learning institutions to in- } \\
\text { troduce new and modern courses is still slow. }\end{array}$ & $\begin{array}{l}\text { The use of curriculum which is what persist now } \\
\text { is good, however I will prefer much more a system } \\
\text { which is flexible, practical and fosters creativity. }\end{array}$ \\
& $\begin{array}{l}\text { 'Focus on current taught subjects are theoretical } \\
\text { and demand students' focus on passing exams I } \\
\text { must admit'. }\end{array}$ \\
\hline $\begin{array}{l}\text { Bureaucratic constraints and lack of support by } \\
\text { major stakeholders. }\end{array}$ & $\begin{array}{l}\text { 'The educational institution function alongside } \\
\text { government agency and to effect a change, take } \\
\text { longer time and money. Hence, the reason for not } \\
\text { catching up with the newer trends of society. }\end{array}$ \\
\hline
\end{tabular}

The research pointed some challenges which could be faced by lecturers in the IR 4.0, this includes (Figure 2.). Speed of technology evolution. Some lecturers admit they would like to learn how to use the new tech tools however the rate at which another is introduced before they are done learning the previous one is overwhelming.

Some fear that schools will in the near future be wired by robotic technology putting their jobs at risk. However, some equally believe that no matter how advanced society progressed in technology it still can't take away the human emotional intelligence which will be the differentiating factor in securing their position as teachers. The research equally pointed out that majority of lecturers would prefer a mix of the traditional system and new technology practice in the higher educational institutions for the training of its students.

Proposals of new courses and or subjects were made to be introduce into the current educational system to enhance students know-how to fit now and into future job market. Some tutors spoke about the STEM (Science, technology, engineering and mathematic) subjects to be made compulsory 
Figure 2: Identified challenges of current educational system and Lecturers fears by Lecturers (Source: according to the www. industry40marketresearch.com, 2019, Amanor-Benedek, qualitative research interviews, $2018 / N=26$ )

\section{Challenges of the current higher educational system}

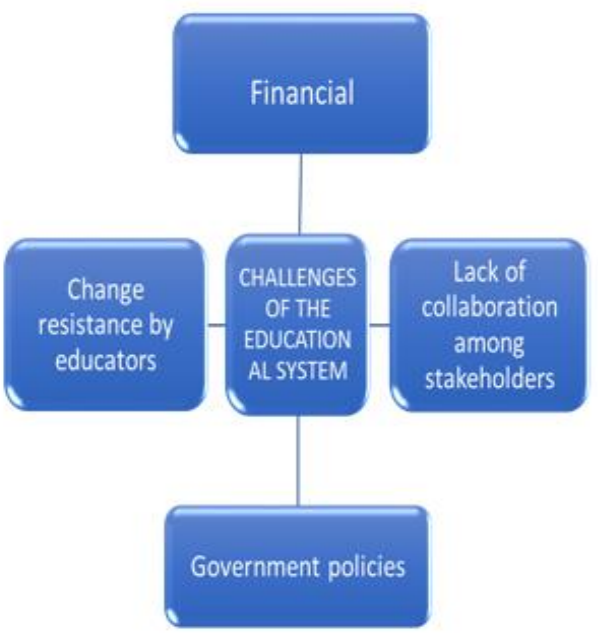

\section{Challenges of educators in education. 4.0}

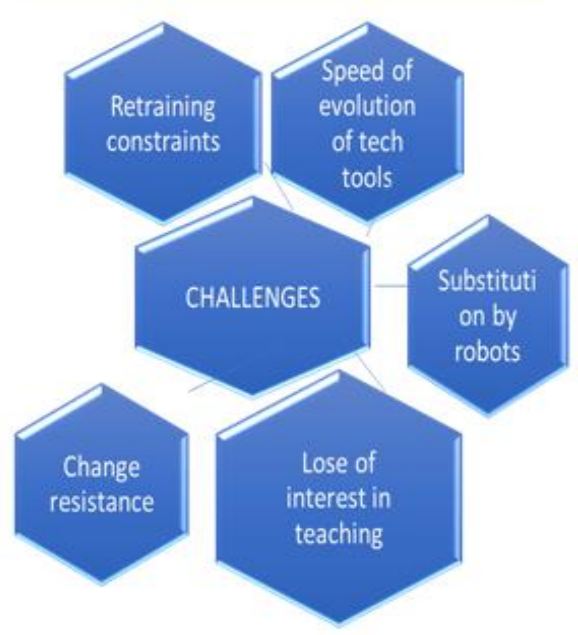

throughout and across the academic ladder. Others proposed that subjects such as creative arts, Innovation and critical thinking and practical reasoning should be taken by all graduate students in the course of their university study.

\section{References}

Babbie, E. (2001). A társadalomtudományi kutatás gyakorlata. Balassi Kiadó, Budapest

Buhr, D. (2015). Social Innovation Policy for Industry 4.0. Tübingen, Germany: Eberhard Karls University of Tübingen.

Forschungsunion, acatech (2013): Securing the future of German manufacturing industry Rec- ommendations for implementing the strategic initiative INDUSTRIE 4.0 Final report of the Industrie 4.0 Working Group 08. April.2013: (download: 2017. december 2.) https://en.acatech.de/publication/recom mendations-for-implementing-thestrategic-initiative-industrie-4-0-finalreport-of-the-industrie-4-0-workinggroup/

MacDougall, W. (2014). Industrie 4.0: Smart Manufacturing for the Future, s.l.: Germany Trade and Invest.

PwC (2017). Industry 4.0: The Current State of Play in Flemish Manufacturing. Press Release. PwC, March 31, 2017. Accessed November 1, 2017: (download: 2017. október.7.) 
https://www.pwc.be/en/news-

publications/press/2017/industry4-0-the-

current-state-of-play-in-flemish-

manufacturing.html

Schwab, K. (2015). The Fourth Industrial Revolution. Geneva: World Economic Forum.

Wallner, T. and Wagener, G. (2016). ACADEMIC EDUCATION 4.0. International Conference on Education and New Developments 2016

Wolter, M. I., Mönnig, A., Hummel, M., Weber, E., Zika, G., Helmrich, R., Maier, T. and Neuber-Pohl C. (2016). Wirtschaft 4.0 und die Folgen für Arbeitsmarkt und Ökonomie Szenario-Rechnungen im Rabmen der BIBBIAB-Qualifikations- und Berufsfeldprojektionen. IAB Forschungsbericht (download: 2017. december 2.) 13/2016 http://doku.iab.de/forschungsbericht/20 16/fb1316.pdf

Xing, B. and Marwala, T. (2017). Implications of the Fourth Industrial Age on Higher Education. 2017.Q.3. Issue 73 p. 6. Institute for Intelligent Systems (IIS) University of Johannesburg (download: 2017. December 7.) https://papers.ssrn. com/sol3/papers.cfm?abstract_id $=32253$ 31

Xing, B. (2017). Visible light based throughput downlink connectivity for the cognitive radio networks. in Spectrum Access and Management for Cognitive Radio Networks. Chapter 8, pp. 211-232, M. A. Matin, Ed., ed Singapore: Springer Science+Business Media, ISBN 978-981-10-2253-1, 2017. 